\title{
COVID-19 in Saudi Arabia
}

\author{
Rehab M A El-Desoukey ${ }^{1 a, 2 *}$, Fawziah M Albarakaty ${ }^{1 b}$, Nabwa $\mathbf{M}^{2}$, \\ Ebtesam $S^{2}$, Abeer $M^{2}$, Yousra $A^{2}$, Wadha $M^{2}$, Mead $\mathbf{G h}^{2}$, Alanoud $S^{2}$ and \\ Jawaher $\mathbf{H}^{2}$ \\ ${ }^{1 a}$ Associate Professor, Microbiology and Immunology Department, National Research \\ Centre, Giza, Egypt \\ ${ }^{1 b}$ Assistant professor, Department of Biology, Faculty of Applied Science,Umm \\ Al-Qura University, Saudi Arabia \\ ${ }^{2}$ Biology Department, Faculty of Science and Humanities in Al Quwai'iyah, Shaqraa \\ University, Saudi Arabia \\ *Corresponding Author: Rehab M A El-Desoukey, E-mail: rehab.eldesoukey@gmail. \\ com
}

Received: November 18, 2021

Published: December 22, 2021

(C) All rights are reserved by Rehab M A

El-Desoukey., et al.

\begin{abstract}
Corona virus COVID-19 is an epidemic whose devastating results had been felt in all corners of the world and via all humanity of something age, gender, monetary and social popularity from the start of January 2020 and the intensity increasing day-by way ofday. The patients that had symptoms had been remoted at the same time as watching for outcomes. In a few international locations, self-isolation changed into encouraged even as in others, humans needed to be installed quarantine facilities to cut down the unfold chain at once. Different nations identified quarantine facilities in which individuals have been quarantined for 14 days upon which they would be examined. A philanthropist Bill gates, the Microsoft billionaire, committed himself to donating assets for growing a vaccine. Research centers directed their attention to organising a treatment or a vaccine for the killer virus. Many governments inside the global carried out a partial or full lockdown guided with the aid of the rate of contamination and death. China became the first to call for a complete lockdown because it struggled with the new pandemic. The COVID-19 pandemic has affected each side of life; social, financial and mental. This has located a lot of strain on governments and people. The financial popularity of many nations and people has been adversely affected and might take a long time earlier than recuperation. This evaluate article aimed to present a wide statistics about the COVID-19 in entire global and awareness on this information related to the ailment in Saudi Arabia.
\end{abstract}

Keywords: Covid 19; Saudi Arabia; Vaccines; Impact; Education; Pathogenesis; Hajj; Umrah; Prevention; Control

\section{Introduction}

COVID-19 is a plague whose devastating consequences have been felt in all corners of the arena and by all humanity of anything age, gender, financial and social status from the start of January 2020 and the depth increasing day-through day. According to Last [1], a plague is "an endemic taking place global, or over a totally huge region, crossing global barriers and generally affect- ing a large range of humans. A Chinese medical doctor, Li Wenliang working in Wuhan city, Hubei in China were given worried about a novel pneumonia-like contamination that turned into turning into commonplace through the day. On thirty first December 2019, the World Health Organization (WHO), China Country Office became knowledgeable of instances of pneumonia of unknown etiology detected in Wuhan City, Hubei Province of China that had infected 
44 people among December and early January 2020 [2]. Later on a comparable disorder became mentioned in other regions of China and outdoor. With the increasing reviews of the little regarded pneumonia-like disorder, its outbreak was declared a Public Health Emergency of International Concern on thirtieth January 2020. WHO monitored the reports on the sickness and its presentation. In due direction, the efforts from medical scientists in one of a kind elements of the arena directed their interest to the study of this novel disease after which it turned into observed to be a kind of corona virus which on eleventh February 2020, changed into named COVID-19 by WHO. The disease shows had been broadcasted in all global media with WHO giving an update of the findings as they got here from properly hooked up researchers and scientists. The disorder inside weeks had spread everywhere in the international and turned into causing devastating consequences. WHO [3] noted that the corona virus COVID-19 pandemic is the defining global fitness disaster of our time and the best assignment confronted given that World War Two. This overview article will supply a top level view of the sickness including the disease and its signs and symptoms, authorities preparedness and its impact. The human corona viruses have been first recognized in the mid-1960s [4]. In the past such viruses blanketed MERS-CoV (the beta corona virus that reasons Middle East Respiratory Syndrome, or MERS) SARS-CoV (the beta corona virus that reasons extreme acute breathing syndrome, or SARS). The viruses originate from birds and more so bats. COVID-19 is a unique virus that caught the world of medics through surprise. Its definition and signs and symptoms keep being revised as new discoveries are made. However, there may be a trendy consensus from scientists that it's far a viral disease that impacts the breathing device. It gets into one's body via the mouth, the nose and the eyes. COVID-19 is in itself a protein which can survive in given surfaces for a various time frame. The virus can jump from animals and infect men after which they may be exceeded from one human to every other. This disqualifies the parable that they jumped out of a lab in Wuhan. Mayo Clinic notes that signs and symptoms of COVID-19 contamination include: fever, cough, tiredness, shortness of breath, trouble respiratory, muscle aches, chills, sore throat, loss of taste and odor, headache and chest pains. It is unfold through contact inside 1 to two meters, respiration droplets spread through sneezing, coughing and talking resulting to droplets being inhaled or land in the mouth or nose of a person nearby and touching surfaces with the virus after which touching ones mouth, nose or eyes
[5]. This review article aimed to offer a huge facts approximately the COVID-19 in complete international and attention in this information associated with the pandemic in Saudi Arabia.

\section{Morphology of corona virus}

Severe acute respiratory syndrome coronavirus 2 (SARS-CoV-2) is a novel extreme acute respiration syndrome coronavirus. It became first remoted from three people with pneumonia linked to the cluster of acute respiratory infection instances in Wuhan [6]. All structural capabilities of the radical SARS-CoV-2 virus particle occur in related coronaviruses in nature [7]. SARS-CoV-2 is intently related to the original SARS-CoV [8]. It is idea to have an animal (zoonotic) starting place. Genetic evaluation has discovered that the coronavirus genetically clusters with the genus Betacoronavirus, in subgenus Sarbecovirus (lineage B) collectively with two batderived lines. It is ninety six\% same at the complete genome stage to different bat coronavirus samples (BatCov RaTG13) [9]. The structural proteins of SARS-CoV-2 include membrane glycoprotein $(\mathrm{M})$, envelope protein (E), nucleocapsid protein $(\mathrm{N})$, and the spike protein (S). The M protein of SARS-CoV-2 is about ninety eight $\%$ similar to the $\mathrm{M}$ protein of bat SARS-CoV, maintains round ninety eight $\%$ homology with pangolin SARS-CoV, and has $90 \%$ homology with the M protein of SARS-CoV; while, the similarity is only round $38 \%$ with the M protein of MERS-CoV. The shape of the M protein resembles the sugar transporter Semi SWEET [10].

\section{History of COVID-19}

The COVID-19 pandemic, also referred to as the coronavirus pandemic, is an. Ongoing pandemic of coronavirus sickness 2019 (COVID-19) because of severe acute breathing syndrome coronavirus 2 (SARS-CoV-2). The sickness turned into first recognized in December 2019 in Wuhan, China [11], became a Public Health Emergency of International Concern in January 2020, and in the end acknowledged as a pandemic. As of 30 September 2020, more than 33.7 million instances were reported global, although the real range of instances is possibly to be a lot better. A better indicator for case unfold is the more than 1.01 million deaths attributed to COVID-19 [12].

The COVID-19 pandemic in Saudi Arabia is part of the worldwide pandemic of coronavirus disorder 2019 (COVID-19) caused by severe acute breathing syndrome coronavirus 2 (SARS-CoV-2). The first case within the nation turned into showed with the aid of 
the Ministry of Health on 2 March 2020 [13] and within the following months, the kingdom held the best quantity of showed cases in the Arab states of the Persian Gulf [14].

\section{Pathogenesis of COVID-19}

Coronavirus ailment 2019 (COVID-19) is a prime fitness subject and can be devastating, mainly for the aged. COVID-19 is the disease due to the SARS-CoV-2 virus. Although a whole lot is thought approximately the mortality of the clinical disease, an awful lot less is understood about its pathobiology. While info of the cell responses to this virus are not known, a likely path of occasions can be postulated based totally on beyond studies with SARS-CoV. A cell biology angle is useful for framing studies questions and explaining the medical route by means of focusing on the regions of the respiratory tract which can be worried. Based at the cells which are in all likelihood inflamed, COVID-19 can be divided into 3 stages that correspond to unique scientific ranges of the disorder [15].

\section{Stage 1: Asymptomatic state (initial 1-2 days of infection)}

The inhaled virus SARS-CoV-2 likely binds to epithelial cells in the nasal cavity and begins replicating. ACE2 is the principle receptor for both SARS-CoV2 and SARS-CoV [16]. In vitro information with SARS-CoV suggest that the ciliated cells are primary cells inflamed within the accomplishing airlines [17]. However, this concept would possibly want a few revision, considering the fact that single-mobile RNA suggests low degree of ACE2 expression in engaging in airway cells and no obvious cell kind choice [18]. There is neighborhood propagation of the virus but a constrained innate immune response.

Stage 2: Upper airway and conducting airway response (next few days)

The virus propagates and migrates down the respiratory tract along the engaging in airways, and a much better innate immune response is brought about. At this time, the sickness COVID-19 is clinically occur. Determining the host innate immune reaction may enhance predictions on the following route of the ailment and need for greater competitive tracking. For approximately eighty $\%$ of the inflamed sufferers, the disorder might be slight and in general confined to the upper and carrying out airlines [15]. These people may be monitored at domestic with conservative symptomatic therapy.

Stage 3: Hypoxia and progression to ARDS
Unfortunately, approximately $20 \%$ of the inflamed patients will progress to level 3 disease and could expand pulmonary infiltrates and some of these will increase very severe disorder. Initial estimates of the fatality fee are around $2 \%$, however this varies markedly with age [15]. The fatality and morbidity charges can be revised as soon as the prevalence of slight and asymptomatic instances is higher defined. The virus now reaches the gas change gadgets of the lung and infects alveolar type II cells. The pathological end result of SARS and COVID-19 is diffuse alveolar harm with fibrin rich hyaline membranes and a few multinucleated large cells [19]. Elderly people are especially at danger because of their dwindled immune response and decreased capacity to restore the broken epithelium. The aged additionally have reduced mucociliary clearance, and this may permit the virus to unfold to the gasoline change units of the lung more simply [20].

\section{The diagnosis of COVID-19}

COVID-19 can provisionally be recognized on the basis of signs and confirmed using opposite transcription polymerase chain reaction (RT-PCR) or other nucleic acid checking out of infected secretions. Along with laboratory trying out, chest CT scans can be beneficial to diagnose COVID-19 in individuals with a high scientific suspicion of contamination. Detection of a beyond infection is possible with serological exams, which come across antibodies produced by using the body in response to the contamination. The popular methods of checking out for presence of SARS-CoV-2 are nucleic acid assessments. Which detects the presence of viral RNA fragments. As those tests come across RNA but not infectious virus, its "capability to determine length of infectivity of patients is constrained." The check is generally achieved on breathing samples received through a nasopharyngeal swab; but, a nasal swab or sputum sample may also be used. Results are typically available inside hours. The WHO has posted numerous checking out protocols for the ailment [21].

Several laboratories and corporations have advanced serological exams, which detect antibodies produced by way of the frame in response to contamination. Several were evaluated through Public Health England and authorized to be used within the UK. The University of Oxford's CEBM has pointed to mounting evidence that "a very good percentage of 'new' slight cases and those re-testing positives after quarantine or discharge from medical institution are not infectious, however are clearly clearing innocent virus debris 
which their immune gadget has effectively dealt with" and have called for "an international effort to standardize and periodically calibrate checking out" On 7 September, the UK authorities issued "guidance for procedures to be carried out in laboratories to offer guarantee of tremendous SARS-CoV-2 RNA effects for the duration of periods of low occurrence, whilst there's a discount within the predictive fee of high quality test consequences" [22].

Chest CT scans may be helpful to diagnose COVID-19 in people with a excessive scientific suspicion of contamination but are not advocated for ordinary screening. Bilateral multilobar groundglass opacities with a peripheral, uneven, and posterior distribution are not unusual in early infection [23]. Subpleural dominance, loopy paving (lobular septal thickening with variable alveolar filling), and consolidation can also appear as the sickness progresses. Characteristic imaging functions on chest radiographs and computed tomography (CT) of those who are symptomatic consist of asymmetric peripheral floor-glass opacities without pleural effusions [39]. Many agencies have created COVID-19 datasets that consist of imagery inclusive of the Italian Radiological Society which has compiled an global on line database of imaging findings for showed instances. Due to overlap with different infections consisting of adenovirus, imaging without affirmation via rRT-PCR is of restricted specificity in identifying COVID-19. A big have a look at in China compared chest CT results to PCR and demonstrated that though imaging is less precise for the infection, it is faster and extra sensitive [24]. In overdue 2019, the WHO assigned emergency ICD10 sickness codes U07.1 for deaths from lab-showed SARS-CoV-2 contamination and U07.2 for deaths from clinically or epidemiologically identified COVID-19 without lab-showed SARS-CoV-2 infection [25].

\section{The mode of infection of COVID-19}

The ailment is especially transmitted through the breathing path while people inhale droplets and small airborne particles (that shape an aerosol) that inflamed humans exhale as they breathe, communicate, cough, sneeze, or sing [26]. Infected people are much more likely to transmit COVID-19 whilst they're bodily close. However, infection can arise over longer distances, mainly indoors. Infectivity can occur 1-three days earlier than the onset of signs and symptoms. Infected individuals can unfold the disease even though they're pre-symptomatic or asymptomatic. Most commonly, the peak viral load in top respiration tract samples happens near the time of symptom onset and declines after the primary week after symptoms begin [27]. Current evidence indicates a period of viral losing and the period of infectiousness of up to 10 days following symptom onset for persons with mild to moderate COVID-19, and a up to twenty days for men and women with extreme COVID-19, consisting of immunocompromised folks. Infectious debris range in length from aerosols that remain suspended in the air for long durations of time to large droplets that stay airborne or fall to the floor [28]. Additionally, COVID-19 studies has redefined the traditional knowledge of the way breathing viruses are transmitted. The largest droplets of respiration fluid do now not tour a ways, and can be inhaled or land on mucous membranes on the eyes, nostril, or mouth to infect. Aerosols are maximum in awareness when human beings are in close proximity, which leads to less complicated viral transmission while people are physically near, but airborne transmission can arise at longer distances, in particular in places that are poorly ventilated; in the ones situations small particles can stay suspended inside the air for mins to hours. The number of people generally infected via one infected man or woman varies; as simplest 10 to $20 \%$ of humans are accountable for the ailment's spread [29]. It often spreads in clusters, wherein infections may be traced back to an index case or geographical area. Often in those instances, superspreading events arise, wherein many people are inflamed through one character [30].

\section{Management and treatment of COVID-19}

Repurposed antiviral tablets make up maximum of the studies into COVID-19 treatments. Other candidates in trials encompass vasodilators, corticosteroids, immune remedies, lipoic acid, bevacizumab, and recombinant angiotensin-converting enzyme 2.In March 2020, the World Health Organization (WHO) initiated the Solidarity trial to assess the remedy consequences of a few promising capsules: an experimental drug known as remdesivir; antimalarial capsules chloroquine and hydroxychloroquine; anti-HIV drugs, lopinavir/ritonavir; and interferon-beta. More than three hundred lively clinical trials are underway as of April 2020 [31]. Research on the antimalarial capsules hydroxychloroquine and chloroquine showed that they have been ineffective at excellent, and that they'll lessen the antiviral pastime of remdesivir. By May 2020, France, Italy, and Belgium had banned using hydroxychloroquine as a COVID-19 remedy. In June, initial effects from the ran- 
domised RECOVERY Trial in the United Kingdom confirmed that dexamethasone decreased mortality by means of one $1 / 3$ for individuals who are severely unwell on ventilators and one fifth for the ones receiving supplemental oxygen. Because this is a well-tested and broadly available treatment, it become welcomed by using the WHO, that's inside the procedure of updating treatment recommendations to encompass dexamethasone and other steroids [32]. Based on those initial results, dexamethasone treatment has been advocated by the NIH for sufferers with COVID-19 who are robotically ventilated or who require supplemental oxygen however now not in sufferers with COVID-19 who do not require supplemental oxygen. In September 2020, the WHO released updated guidance on using corticosteroids for COVID-19. The WHO recommends systemic corticosteroids instead of no systemic corticosteroids for the treatment of humans with excessive and important COVID-19 (robust recommendation, based totally on mild reality proof). The WHO suggests not to use corticosteroids within the remedy of humans with non-intense COVID-19 (conditional advice, primarily based on low truth evidence). The updated steering changed into primarily based on a meta-analysis of scientific trials of significantly sick COVID-19 patients [33]. In September 2020, the European Medicines Agency (EMA) advocated using dexameth- asone in adults and young people from twelve years of age and weighing as a minimum 40 kilograms (88 lb) who require supplemental oxygen therapy. Dexamethasone may be taken by using mouth or given as an injection or infusion (drip) into a vein. In November 2020, the U.S. Food and Drug Administration (FDA) issued an emergency use authorization for the investigational monoclonal antibody remedy bamlanivimab for the treatment of moderate-to-moderate COVID-19. Bamlanivimab is permitted for humans with high-quality consequences of direct SARS-CoV-2 viral checking out who're twelve years of age and older weighing at least 40 kilograms ( $88 \mathrm{lb}$ ), and who are at high risk for progressing to extreme COVID-19 or hospitalization. This consists of people who are 65 years of age or older, or who've chronic medical conditions. In February 2021, the FDA issued an emergency use authorization (EUA) for bamlanivimab and etesevimab administered together for the remedy of slight to mild COVID-19 in humans twelve years of age or older weighing at the least forty kilograms (88 lb) who test effective for SARS-CoV-2 and who are at excessive danger for progressing to intense COVID-19. The legal use includes treatment for people who are sixty five years of age or older or who have positive chronic scientific conditions [34]. The treatment protocol in Saudi Arabia clarified in table 1.

\begin{tabular}{|c|c|c|c|c|}
\hline \multirow[t]{3}{*}{$\begin{array}{l}\text { Suspicious Cases } \\
\text { (follow case definition } \\
\text { published in Saudi } \\
\text { CDC guidelines) }\end{array}$} & $\begin{array}{l}\text { Mild to Moderate: } \\
\text { Symptoms with no } \\
\text { shortness of breath }\end{array}$ & $\begin{array}{c}\text { Treat symptoms } \\
\text { If no hospital admission re- } \\
\text { quired, need to follow instruc- } \\
\text { tions and recommendations } \\
\text { published by Saudi CDC https:// } \\
\text { covid19.cdc.gov.sa/ profession- } \\
\text { als-health- } \\
\text { workers/ }\end{array}$ & $\begin{array}{c}\text { Not required } \\
\text { Do not stop ACEI/ARBs } \\
\text { in patients with hyper- } \\
\text { tension, post-MI, or } \\
\text { heart failure }\end{array}$ & \multirow[t]{4}{*}{$\begin{array}{l}\text { Paracetamol (acetaminophen) } \\
\text { is the prefered agent for pain/ } \\
\text { fever see below table "Medication } \\
\text { Related Information" } \\
\text { Labs and work-up: CBC, Urea/ } \\
\text { Electrolytes, Creatinine, CRP, LFTs, } \\
\text { Chest X-ray, COVID-19 PCR tests }\end{array}$} \\
\hline & $\begin{array}{l}\text { Mild to Moderate: } \\
\text { Symptoms with no } \\
\text { shortness of breath } \\
\text { in high risk patients } \$\end{array}$ & \multirow{2}{*}{$\begin{array}{l}\text { Treat symptoms } \\
\text { If hospital admission is not } \\
\text { required, follow instructions and } \\
\text { recommendations published by } \\
\text { Saudi CDC https://covid19.cdc. } \\
\text { gov.sa/ professionals-health- } \\
\text { workers/ } \\
\text { Consult Infectious Disease } \\
\text { Specialist }\end{array}$} & \multirow{2}{*}{$\begin{array}{l}\text { Case shall be discussed } \\
\text { with infectious disease } \\
\text { specialist, to initiate } \\
\text { empirical antiviral } \\
\text { therapy, while awaiting } \\
\text { PCR result. } \\
\text { Do not stop ACEI/ARBs } \\
\text { in patients with hyper- } \\
\text { tension, post-MI, heart } \\
\text { failure } \\
\text { If decision is to treat } \\
\text { empirically, follow the } \\
\text { treatment option under } \\
\text { confirmed by PCR }\end{array}$} & \\
\hline & $\begin{array}{l}\text { Mild to Moderate: } \\
\text { Symptoms with } \\
\text { shortness of breath } \\
\text { in high risk patients } \$\end{array}$ & & & \\
\hline $\begin{array}{c}\text { PCR } \\
\text { Confirmed Cases }\end{array}$ & Asymptomatic & $\begin{array}{l}\text { Follow instructions and recom- } \\
\text { mendations published by Saudi } \\
\text { CDC https://covid19.cdc.gov.sa/ } \\
\text { professionals-health- workers/ }\end{array}$ & Not required & \\
\hline
\end{tabular}




\begin{tabular}{|c|c|c|c|c|}
\hline $\begin{array}{c}\text { PCR } \\
\text { Confirmed Cases }\end{array}$ & $\begin{array}{l}\text { Mild to Moderate: } \\
\text { Symptoms (no } 02 \\
\text { requirements/no } \\
\text { evidence of pneumo- } \\
\text { nia but with other } \\
\text { symptoms of covid- } \\
19 \text { e.g. fever) }\end{array}$ & $\begin{array}{l}\text { Treat symptoms } \\
\text { Follow instructions and recom- } \\
\text { mendations published by Saudi } \\
\text { CDC https://covid19.cdc.gov.sa/ } \\
\text { professionals-health- workers/ }\end{array}$ & $\begin{array}{l}\text { Consider starting any of } \\
\text { the following according } \\
\text { to clinical evaluation } \\
\text { and treating consultant's } \\
\text { discretion): } \\
\text { Triple combination } \\
\text { therapy (for adults): } \\
\text { Lopinavir / Ritonavir, } \\
\text { Ribavirin and interferon } \\
\text { beta-1b for 14-days. } \\
\text { Start within } 7 \text { days from } \\
\text { symptoms appearance. } \\
\text { - Lopinavir /Rito- } \\
\text { navir } \\
\text { Adult Dosing: } \\
400 / 100 \text { mg } \\
\text { (2 tablets of } \\
200 / 50 \text { mg) } \\
\text { every } 12 \text { hrs. } \\
\text { - Ribavirin } \\
\text { Adult Dosing: } \\
400 \text { mg every } \\
12 \mathrm{hrs} \\
\text { Interferon beta-1b } \\
\text { Adult Dosing: } \\
8 \text { MIU on al- } \\
\text { ternative days } \\
\text { for } 3 \text { doses. }\end{array}$ & 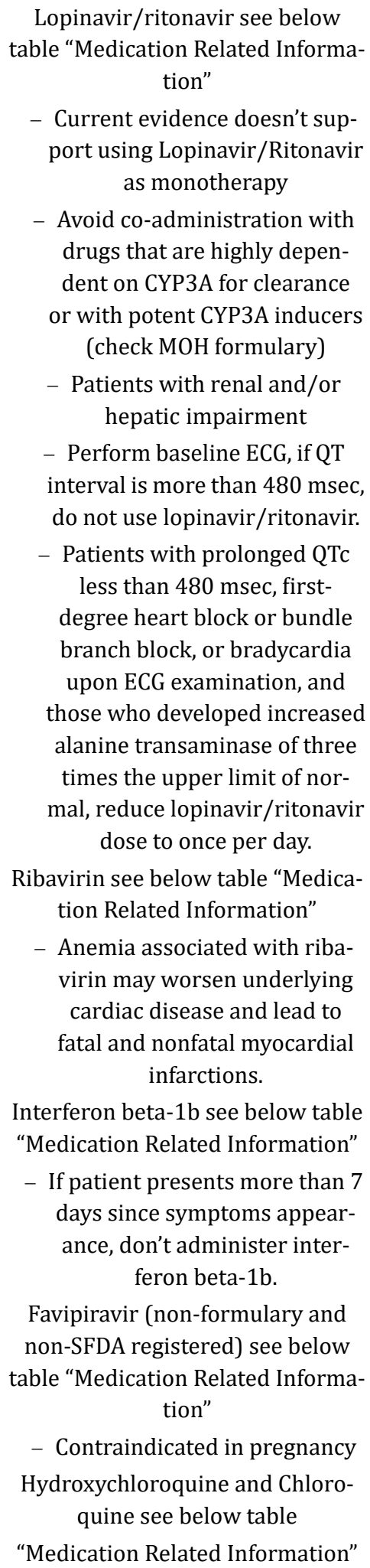 \\
\hline
\end{tabular}




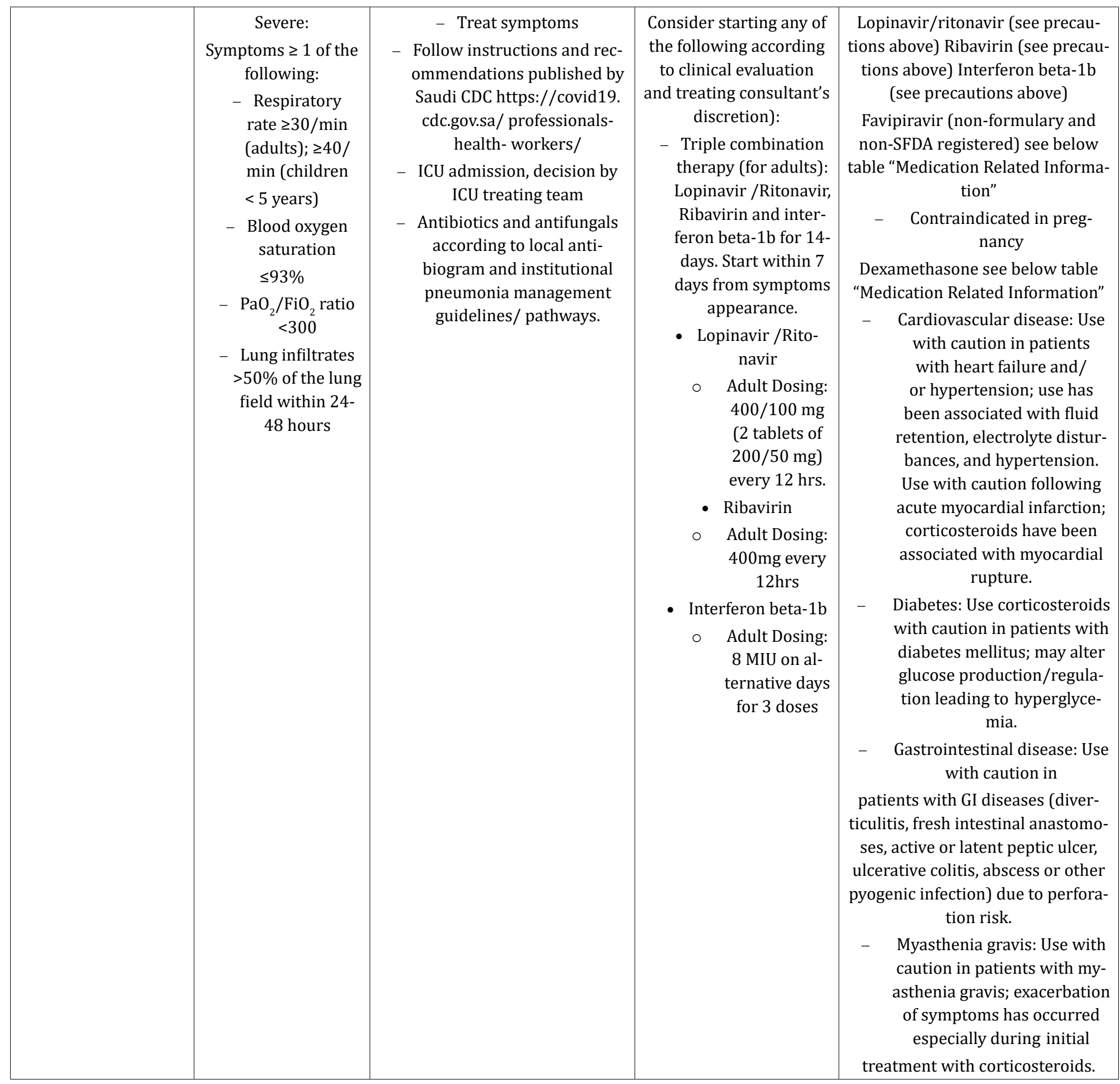




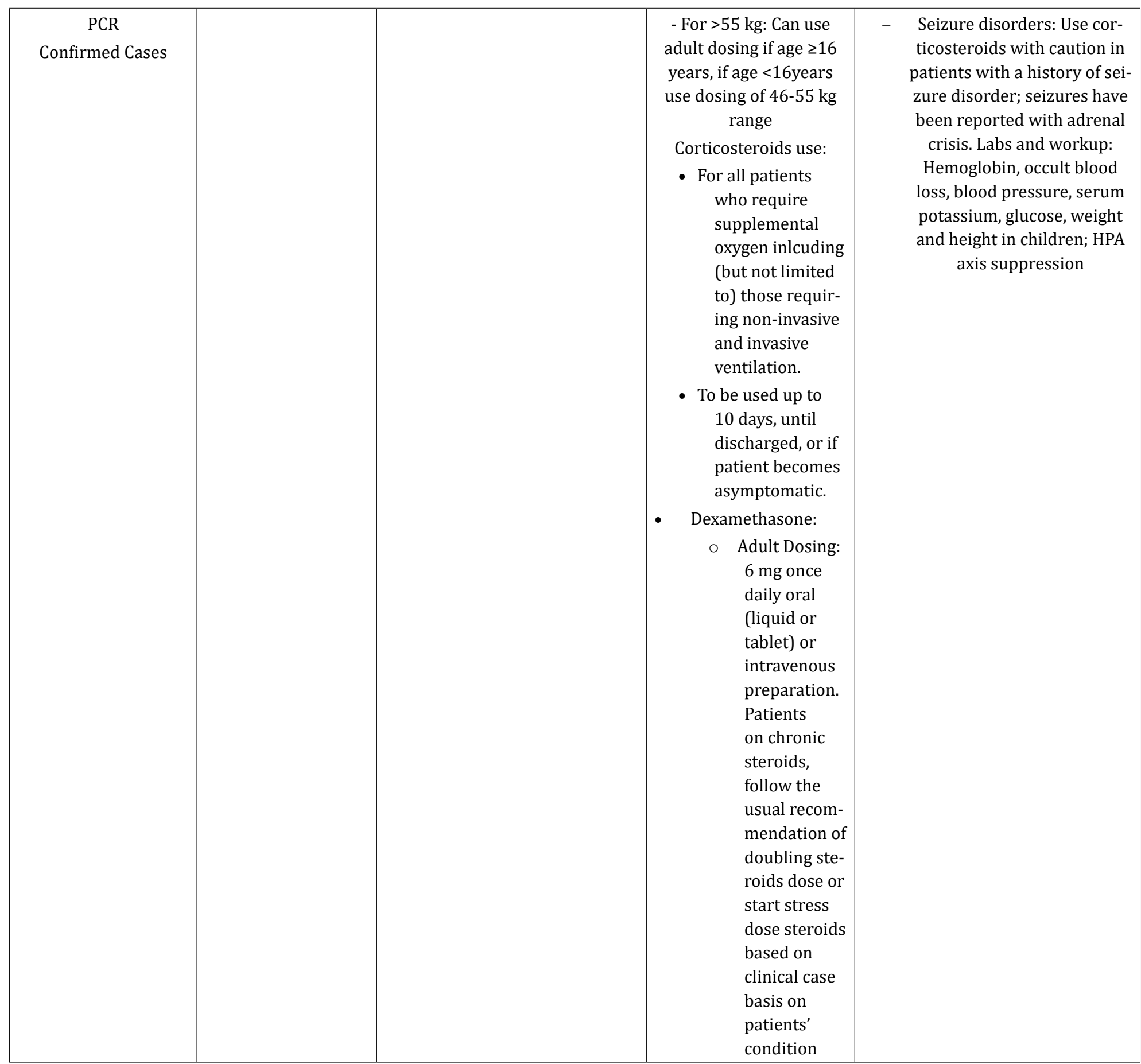




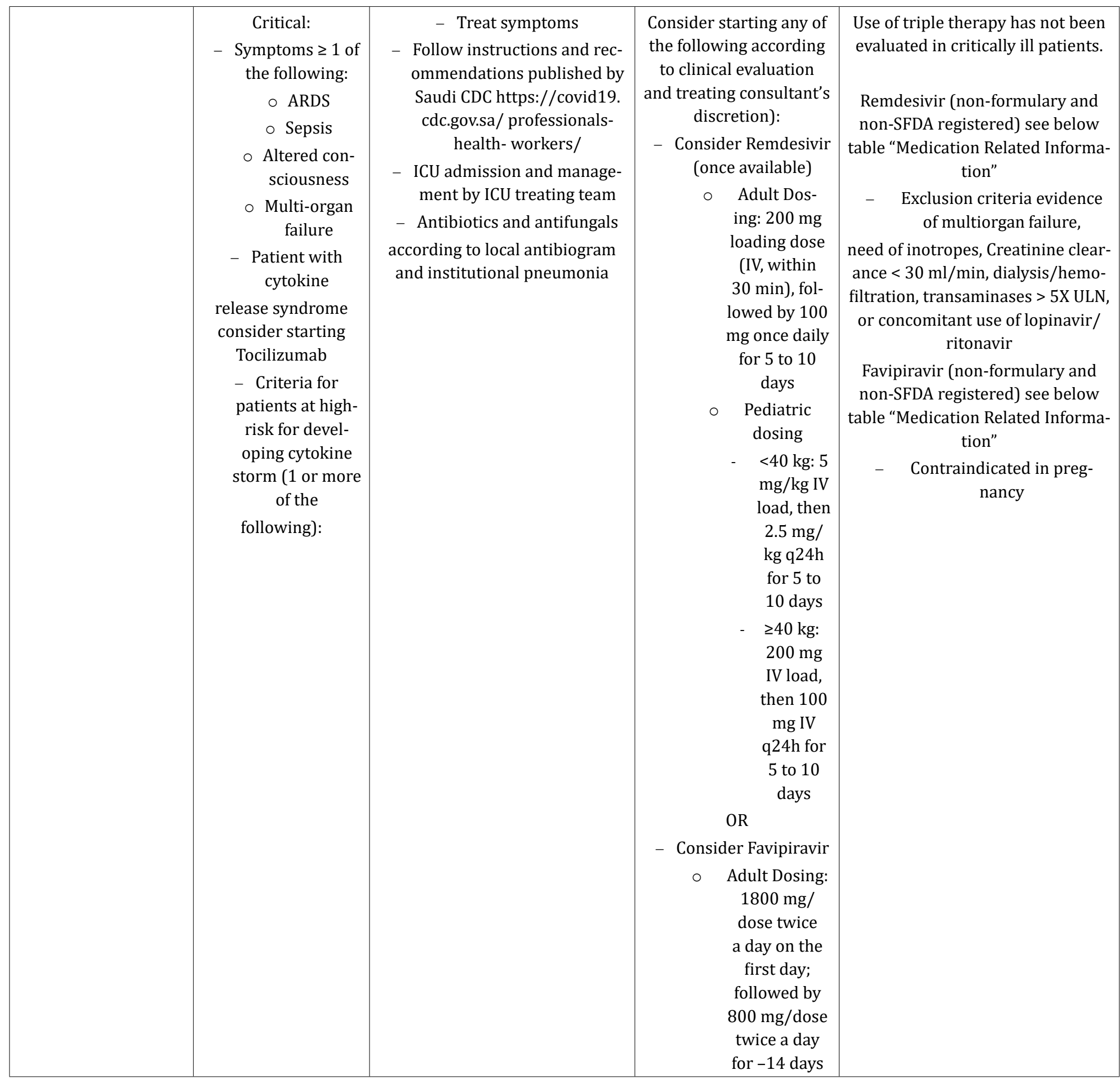

Table 1: Saudi MoH Protocol for Patients Suspected of/Confirmed with COVID-19/Supportive care and antiviral treatment of suspected or confirmed COVID-19 infection/ (Version 2.1) July 31 ${ }^{\text {st }}, 2020$ [35] 


\section{Prevention and control of COVID-19}

A COVID-19 vaccine is not anticipated till 2021 at the earliest. The US National Institutes of Health tips do not advocate any medicine for prevention of COVID-19, before or after publicity to the SARS-CoV-2 virus, out of doors the setting of a medical trial [36]. Without a vaccine, different prophylactic measures, or powerful remedies, a key a part of dealing with COVID-19 is making an attempt to decrease and postpone the epidemic top, known as "knocking down the curve". This is completed by slowing the contamination rate to lower the hazard of fitness offerings being crushed, making an allowance for better treatment of current instances, and delaying extra cases till effective treatments or a vaccine end up available. Preventive measures to reduce the chances of contamination include staying at home, wearing a masks in public, keeping off crowded places, preserving distance from others, ventilating indoor areas, washing fingers with cleaning soap and water frequently and for at least 20 seconds, practising excellent respiration hygiene, and averting touching the eyes, nose, or mouth with unwashed fingers. Those recognized with COVID-19 or who agree with they'll be inflamed are suggested by way of the CDC to live domestic except to get medical care, call beforehand before visiting a healthcare provider, put on a face mask before entering the healthcare issuer's workplace and whilst in any room or vehicle with every other individual, cover coughs and sneezes with a tissue, often wash fingers with soap and water and keep away from sharing non-public household objects. The global is in the midst of a COVID-19 pandemic. As WHO and partners work together on the reaction -- monitoring the pandemic, advising on crucial interventions, dispensing crucial clinical elements to the ones in need-- they are racing to expand and installation safe and powerful vaccines. Vaccines keep millions of lives each yr. Vaccines paintings by means of education and getting ready the frame's herbal defences the immune gadget - to understand and combat off the viruses and micro organism they goal. After vaccination, if the frame is later uncovered to those ailment-causing germs, the frame is without delay equipped to destroy them, preventing infection [37].

On 27 December 2020, the Kingdom's Ministry of Health announced extra than 700,000 human beings had registered to receive the coronavirus vaccine for the reason that vaccination registration campaign began on 17 December. On 29 December 2020, the Kingdom's Health Minister Tawfiq al-Rabiah, told Al Arabiya, coronavirus vaccines are set to reach all areas of Saudi Arabia within three weeks. On 19 January 2021 Saudi Arabia authorised AstraZeneca and additionally Moderna vaccines to be used against the Coronavirus. In March 2021, Saudi Health Minister Tawfiq alRabiah said that the Kingdom will offer the vaccinations to the pharmacies for free knowing that extra than one hundred vaccination centers have opened across the USA. On March 9, the overall of vaccination centres became 32 after starting 26 news centers via Asir Health Affairs [38]. On March 25, 2021, Saudi Arabia stated that every one home people affiliated with recruitment corporations in Saudi Arabia must get the vaccine. Otherwise, they should offer a weekly bad PCR take a look at result on the expense of the organization. In April 2021, Saudi Arabia postponed the appointments of the second dose for COVID-19 vaccines to be able to make sure that greater citizens can receive the primary dose. By April 14, Saudi Arabia had vaccinated 6,450,278 human beings [39]. In May 2021, Saudi government stated that, beginning August 2021, attending occasions, whether or not social, medical, financial cultural or different, and coming into any authorities or non-public establishment will require having the Covid-19 immunization [40].

\begin{tabular}{|c|c|c|c|}
\hline Date & & \# of cases & \# of deaths \\
\hline 2021-05-08 & 工 & $425442(+0.5 \%)$ & $7072(+14)$ \\
\hline 2021-05-09 & 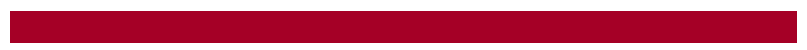 & $426384(+0.5 \%)$ & $7072(+13)$ \\
\hline
\end{tabular}

Citation: Rehab M A El-Desoukey., et al. "COVID-19 in Saudi Arabia". Acta Scientific Microbiology 5.1 (2022): 33-47. 


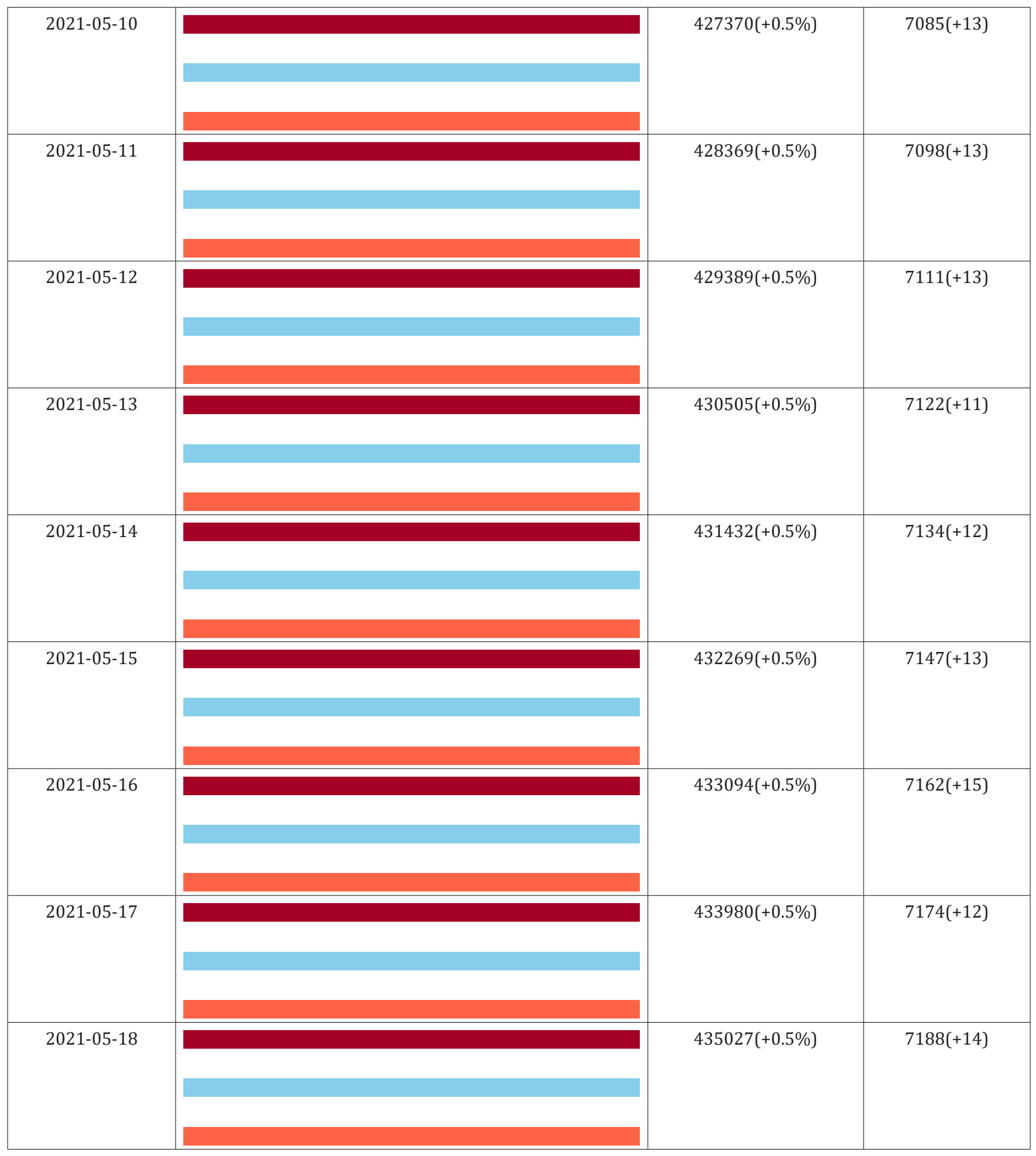




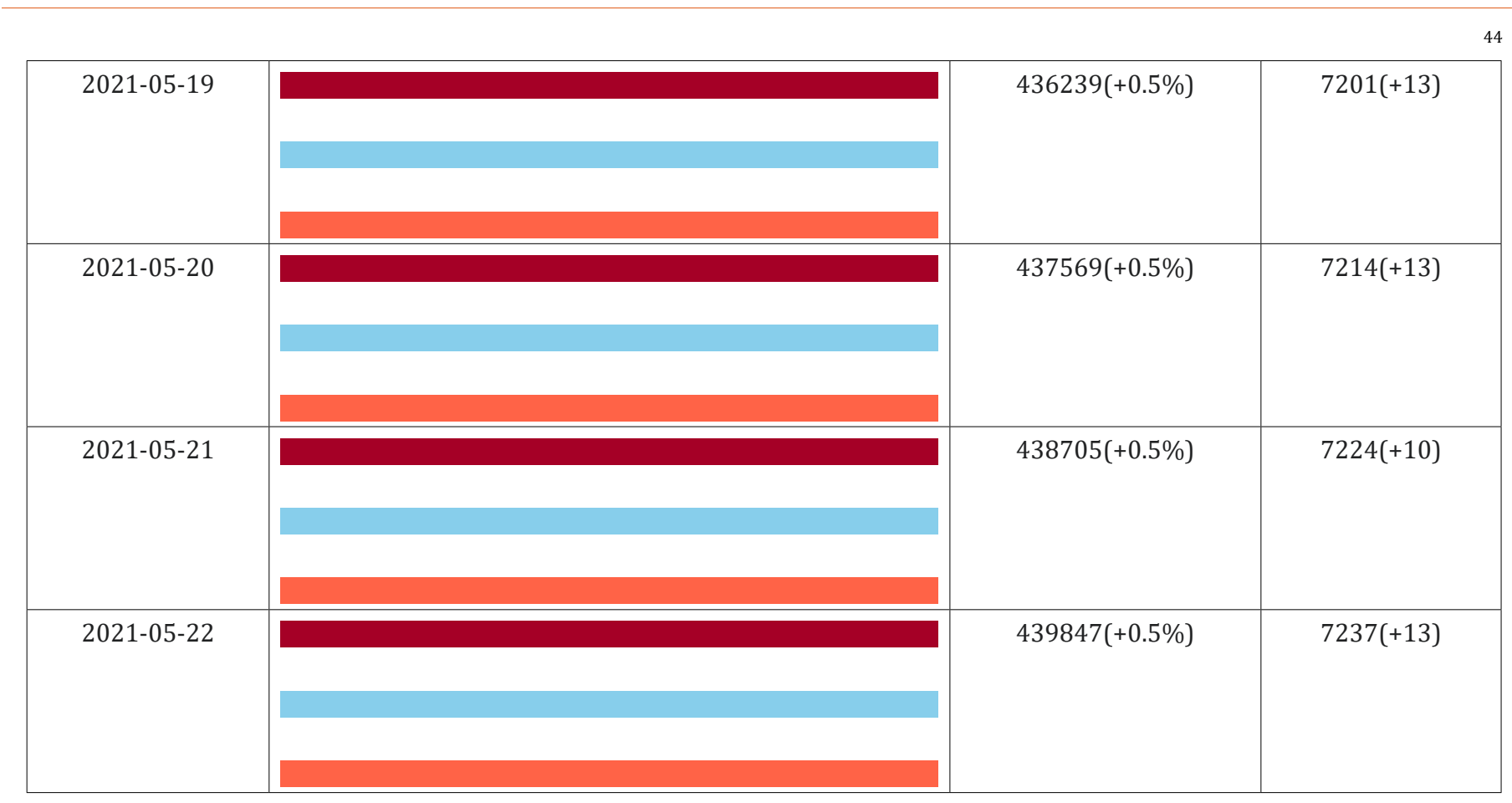

Table 2: COVID-19 cases in Saudi Arabia /2020-2021/ Jan Feb Mar Apr May/Last 15 days/ [41-45].

Deaths; Recoveries; Active cases.

\section{Impact of COVID-19 on education}

The G20 Education Ministers emphasised that the measures taken to include the outbreak of the Coronavirus have profoundly affected training and many factors of existence, and the prolonged closure of educational establishments has affected teachers, educators, students and their households everywhere in the international, such as growing and least evolved countries, as Education structures in those international locations confronted additional demanding situations at the same time as responding to the pandemic [46]. The Ministry of Education in Saudi Arabia has taken precautionary measures to prevent the spread of the Coronavirus, by means of making ready numerous implementation plans at the level of the ministry, educational departments and colleges, in cooperation with the Ministry of Health. The measures to be taken encompass informing all training departments of the mechanism of admission strategies for students returning from the People's Republic of China and the countries where the virus has spread, and the approaches obtained from the National Center for Disease Prevention and Control in the Ministry of Health The sources on which the space education machine depends are the usage of pub- lic and private libraries, via revealed and digital books in them. The use of recorded instructional materials which includes audio or video recording of instructions and lectures by way of teachers and broadcast them thru the Internet or television. Laboratories and schooling websites [47].

\section{Impact of COVID-19 on hajj and umrah}

The COVID-19 pandemic affected the 2020 Hajj (pilgrimage), that is the fifth pillar of the Five Pillars of Islam, wherein hundreds of thousands of Muslims from round the sector go to Mecca and Medina every year throughout Hajj season for a week. Over 2,four hundred,000 pilgrims attended Hajj in 2019 [48]. In March 2020, the minister of Hajj and Umrah advocated those planning to visit the holy web sites of Mecca and Medina later in the 12 months to wait before making any bookings. Due to the notably contagious nature of COVID-19 in crowded locations, flight restrictions in many countries, and the unavailability of a vaccine against the virus the ministry of Hajj and Umrah took such serious measures [49]. However, in June 2020, the ministry of Hajj and Umrah introduced that human beings from all nationalities who are living in 
Saudi Arabia are allowed to perform Hajj with a restricted number of pilgrims, to make certain the safety and to prevent the transmission of COVID-19 [50].

\section{Conclusion and Recommendations}

COVID-19 is a virus unfold in the global. People who be afflicted by immunodeficiency, the elderly and sufferers with incurable sicknesses must inn to protection from the epidemic by using taking precautionary measures and taking the vaccines permitted by the World Health Organization. Accordingly, the Kingdom of Saudi Arabia has taken all precautionary measures in all fields and turned into at the vanguard of nations in growing a success treatment protocol.

\section{Bibliography}

1. Last JM. "A dictionary of epidemiology". $4^{\text {th }}$ edition. New York: Oxford University Press (2001).

2. WHO. "Who Names Disease Caused By New Corona virus: COVID-19” (2020).

3. WHO. "Novel Corona virus (2019-nCoV) Situation Report" (2020).

4. CDC. "Human Corona virus types" (2020).

5. Mayo Clinic. “Corona virus disease (COVID-19)” (2020).

6. “Outbreak of severe acute respiratory syndrome coronavirus 2 (SARS-CoV-2): increased transmission beyond China - fourth update". European Centre for Disease Prevention and Control (2020).

7. Andersen KG., et al. "The proximal origin of SARS-CoV-2". Nature Medicine 26.4 (2020): 450-452.

8. Zhu N., et al. "A Novel Coronavirus from Patients with Pneumonia in China, 2019". The New England Journal of Medicine 382.8 (2020): 727-733.

9. "Report of the WHO-China Joint Mission on Coronavirus Disease 2019 (COVID-19)". World Health Organization (WHO) (2020).

10. Thomas S. "The Structure of the Membrane Protein of SARSCoV-2 Resembles the Sugar Transporter SemiSWEET". Pathogens and Immunity 5.1 (2020): 342-363.
11. Mousavizadeh L and Ghasemi S. "Genotype and phenotype of COVID-19: Their roles in pathogenesis". Journal of Microbiology, Immunology and Infection 54.2 (2021): 159-163.

12. Page J., et al. "In Hunt for Covid-19 Origin, Patient Zero Points to Second Wuhan Market - The man with the first confirmed infection of the new coronavirus told the WHO team that his parents had shopped there". The Wall Street Journal (2021).

13. Zimmer C. "The Secret Life of a Coronavirus - An oily, 100-nanometer-wide bubble of genes has killed more than two million people and reshaped the world. Scientists don't quite know what to make of it" (2021).

14. "Saudi Arabia announces the first case of coronavirus". Arab News. Riyadh: Saudi Research and Marketing Group. 3 March 2020. ISSN 0254-833X. Archived from the original on 2 March 2020. Retrieved 4 April 2020. Saudi Arabia reported its first case of the new coronavirus on Monday amid growing fears that a surge in the number of those infected in Iran is threatening the whole region (2020).

15. “Covid 19 Dashboard: Saudi Arabia” (2020).

16. Wu Z and McGoogan JM. "Characteristics of and important lessons from the coronavirus disease 2019 (COVID-19) outbreak in China: summary of a report of 72314 cases from the Chinese Center for Disease Control and Prevention". JAMA (2020).

17. Hoffmann M., et al. "SARS-CoV-2 cell entry depends on ACE2 and TMPRSS 2 and is blocked by a clinically proven protease inhibitor". Cell (2020).

18. Sims AC., et al. "Severe acute respiratory syndrome coronavirus infection of human ciliated airway epithelia: role of ciliated cells in viral spread in the conducting airways of the lungs". Journal of Virology 79 (2005): 15511-15524.

19. Reyfman PA., et al. "Single-cell transcriptomic analysis of human lung provides insights into the pathobiology of pulmonary fibrosis". American Journal of Respiratory and Critical Care Medicine 199 (2019): 1517-1536.

20. Xu Z., et al. "Pathological findings of COVID-19 associated with acute respiratory distress syndrome". Lancet Respiratory Medicine 8 (2020): 420-422. 
21. Bullard J., et al. "Predicting Infectious Severe Acute Respiratory Syndrome Coronavirus 2 From Diagnostic Samples". Clinical Infectious Diseases 71.10 (2020): 2663-2666.

22. "NHS staff will be first to get new coronavirus antibody test, medical chief promises". The Independent (2020).

23. Lu J., et al. "Clinical, immunological and virological characterization of COVID-19 patients that test re-positive for SARSCoV-2 by RT-PCR". EBioMedicine 59 (2020): 102960.

24. "SARS-CoV-2 RNA testing: assurance of positive results during periods of low prevalence". GOV.UK (2020).

25. Lee EY., et al. "COVID-19 pneumonia: what has CT taught us?". The Lancet Infectious Diseases 20.4 (2020): 384-385.

26. Li Y and Xia L. "Coronavirus Disease 2019 (COVID-19): Role of Chest CT in Diagnosis and Management". AJR. American Journal of Roentgenology 214.6 (2020): 1280-1286.

27. "ICD-10 Version:2019". World Health Organization (WHO). 2019. Archived from the original on 31 March 2020. Retrieved 31 March 2020. U07.2 - COVID-19, virus not identified - COVID-19 NOS - Use this code when COVID-19 is diagnosed clinically or epidemiologically but laboratory testing is inconclusive or not available. Use additional code, if desired, to identify pneumonia or other manifestations

28. Miller SL., et al. "Transmission of SARS-CoV-2 by inhalation of respiratory aerosol in the Skagit Valley Chorale superspreading event". Indoor Air 31.2 (2021): 314-323.

29. Communicable Diseases Network Australia. "Coronavirus Disease 2019 (COVID-19): CDNA National Guidelines for Public Health Units". 5.1. Communicable Diseases Network Australia/Australian Government Department of Health.

30. "Clinical Questions about COVID-19: Questions and Answers". Centers for Disease Control and Prevention (2021).

31. Kupferschmidt K and Cohen J. "WHO launches global megatrial of the four most promising coronavirus treatments". Science (2020).

32. "WHO welcomes preliminary results about dexamethasone use in treating critically ill COVID-19 patients". World Health Organization (WHO) (Press release) (2020).
33. Prescott HC and Rice TW. "Corticosteroids in COVID-19 ARDS: Evidence and Hope During the Pandemic". JAMA 324.13 (2020): 1292-1295.

34. "FDA Authorizes Monoclonal Antibodies for Treatment of COVID-19". U.S. Food and Drug Administration (FDA) (Press release). This article incorporates text from this source, which is in the public domain (2021).

35. Ministry of Health. Coronavirus Diseases 19 (COVID-19) guidelines (2020).

36. “COVID-19 Treatment Guidelines". www.nih.gov. National Institutes of Health (2020).

37. Centers for Disease Control and Prevention (5 April 2020). "What to Do if You Are Sick". U.S. Centers for Disease Control and Prevention (CDC) (2020).

38. "26 more vaccination centers opened in Saudi Arabia's Asir region to fight COVID-19". Arab News (2021).

39. "Saudi Arabia postpones second COVID-19 dose reservations". Arab News (2021).

40. "Saudi Arabia to require COVID-19 immunization for entering events starting August". Arab News (2021).

41. "Saudi Arabia detects 24 cases of coronavirus, total rises to 86". Al Arabiya (2019).

42. "Saudi Arabia announces 17 new cases of coronavirus". Arab News (2019).

43. "Ministry of Health Reports 15 New Cases of Coronavirus". Saudi Press Agency (2020).

44. "Ministry of Health Reports 15 New Cases of COVID-19". Saudi Press Agency (2020).

45. "Ministry of Health Reports 38 New Cases of COVID-19". Saudi Press Agency (2020).

46. https://www.spa.gov.sa/2102851

47. https://www.moe.gov.sa/ar/news/Pages/co-2579.aspx

48. "Abstract of Hajj Statistics $1440 \mathrm{H}$ ".

49. "Saudi Arabia asks Muslims to delay Hajj bookings". BBC News (2020). 
50. Hamdi Alkhshali, Larry Register. "Saudi Arabia says Hajj pilgrimage is on -- with limited numbers". CNN (2020).

\section{Assets from publication with us}

- Prompt Acknowledgement after receiving the article

- Thorough Double blinded peer review

- Rapid Publication

- Issue of Publication Certificate

- High visibility of your Published work

Website: www.actascientific.com/

Submit Article: www.actascientific.com/submission.php

Email us: editor@actascientific.com

Contact us: +919182824667 